\title{
Pengaruh Interaksi Genotipe dengan Lingkungan terhadap Kandungan Fe Biji Padi
}

\section{Effect of Environment Interaction on Fe Rice Content}

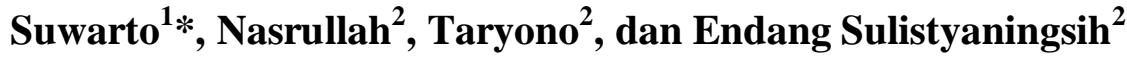 \\ ${ }^{1}$ Fakultas Pertanian Universitas Jenderal Soedirman Purwokerto \\ ${ }^{2}$ Program Pasca Sarjana Universitas Gadjah Mada Yogyakarta \\ E-mail: oryza_07@yahoo.com *Penulis untuk korespondensi
}

\begin{abstract}
To explore the effect of genotype, environment and genotype $x$ environment interaction on Fe content in rice grain, Fe concentrations of 10 genotypes were analyzed across eight paddy field environments using the GGE-biplot method. Experiments were conducted from 2007 to 2008 using a randomized completely block design with three replications at each environment. Results indicated that environment $(E)$, genotype $(G)$ and genotype $x$ environment interaction (GE) significantly gave effect on Fe rice concentration. Environment explained $74.43 \%$ of total $(G+E+G E)$ variation, whereas $G$ and $G E$ captured $5.60 \%$ and $19.67 \%$, respectively. The first two principal components (PC1 and PC2) were used to create a two-dimensional GGE-biplot and explained $70.40 \%$ and $15.36 \%$ of GGE sum of squares. Genotype Barumun was desirable in terms of its highest Fe rice concentration ability and stability. In Cilongok, wet season was the best representative of the overall environments and the most powerful to discriminate genotypes.
\end{abstract}

Key words: Fe rice content, genotype, environment, interaction, GGE-biplot

\begin{abstract}
Abstrak
Untuk mempelajari pengaruh genotipe, lingkungan dan interaksi genotipe dengan lingkungan pada kandungan Fe beras, data kandungan Fe beras 10 genotipe padi pada 8 lingkungan dianalisis menggunakan metode GGE-biplot. Penelitian dilaksanakan tahun 2007-2008 menggunakan rancangan acak kelompok lengkap tiga ulangan. Tujuan penelitian adalah untuk mempelajari pengaruh genotipe, lingkungan dan interaksi genotipe dengan lingkungan pada kandungan Fe beras. Hasil penelitian menunjukkan lingkungan, genotipe dan interaksinya berpengaruh nyata terhadap kandungan Fe beras. Lingkungan menjelaskan 74,43\% dari variasi total $(G+E+G E)$, sedangkan $G$ dan $G E$ menjelaskan $5,60 \%$ dan $19,67 \%$. Dua komponen utama (PC1 dan PC2) digunakan untuk membuat grafik GGE-biplot, menjelaskan $\mathbf{7 0 , 4 0 \%}$ dan $\mathbf{1 5 , 3 6 \%}$ dari JK (jumlah kuadrat) GGE. Genotipe Barumun merupakan genotipe ideal karena memiliki kandungan Fe beras tertinggi dan paling stabil. Lingkungan Cilongok musim hujan merupakan lingkungan terbaik karena paling representatif mewakili semua lingkungan dan paling kuat untuk membedakan antar genotipe.
\end{abstract}

Kata kunci: Fe beras, genotipe, lingkungan, interaksi, GGE-biplot

Diterima: 05 Maret 2009, disetujui: 03 Maret 2010

\section{Pendahuluan}

Menurut Graham dan Welch (2002, 2004), biofortifikasi adalah kegiatan pemuliaan tanaman untuk meningkatkan kandungan nutrisi pada produk tanaman. Hasil biofortifikasi adalah varietas unggul baru yang memiliki kandungan nutrisi tinggi (Gregorio et al., 2005; Winarsi,
2007). Melalui biofortifikasi Fe pada tanaman padi akan tersedia varietas unggul padi yang memiliki kandungan Fe beras tinggi yang secara alami dapat mengurangi atau mencegah penyakit yang disebabkan oleh defisiensi Fe (Anemia).

Biofortifikasi Fe akan berjalan efektif jika didukung dengan informasi ilmiah tentang kandungan nutrisi Fe dalam beras. Salah satu 
informasi yang sangat penting adalah bagaimana genotipe, lingkungan, dan interaksinya mempengaruhi kandungan nutrisi $\mathrm{Fe}$ beras. Informasi tersebut menentukan berbagai aspek dan strategi pemuliaannya.

Interaksi genotipe dengan lingkungan sifat kandungan $\mathrm{Fe}$ beras yang nyata dapat secara serius mengganggu usaha seleksi memilih genotipe superior dalam program pengembangan genotipe baru (Shafii dan Price, 1998). Seleksi memilih genotipe baru berkadar Fe beras tinggi tidak cukup dilakukan pada satu lingkungan. Interaksi genotipe dengan lingkungan sifat kandungan $\mathrm{Fe}$ beras yang nyata memengaruhi program pengembangan genotipe baru, pengembangan genotipe yang berbeda untuk lingkungan dan kondisi iklim berbeda (Busey, 1983).

Informasi pola interaksi genotipe dengan lingkungan bermanfaat bagi pemulia tanaman untuk membantu mengembangkan suatu genotipe yang ditujukan untuk semua lingkungan atau genotipe spesifik pada target lingkungan tertentu (Bridges, 1989). Informasi interaksi genotipe dengan lingkungan kandungan nutrisi $\mathrm{Fe}$ beras yang melibatkan genotipe padi dan lingkungan di Indonesia belum pernah dilaporkan.

Data hasil pengujian pertumbuhan dan produksi berbagai genotipe pada berbagai lingkungan memiliki tipe komplek, karena ada pengaruh genotipe, lingkungan dan interaksinya. Data tersebut perlu dianalisis dan disajikan dalam bentuk yang mudah dipahami, mudah diinterpretasikan dan memiliki akurasi yang tinggi. Teknik grafik biplot merupakan suatu alat yang sangat membantu memahami visualisasi data tersebut (Yan et al., 2000; Yan, 2001 dan 2002; Yan dan Kang, 2003).

Grafik biplot yang menampilkan hubungan genotipe dan lingkungan, banyak digunakan untuk menampilkan hasil analisis AMMI (Additive Main Effect and Multiplicative Interaction) (Gauch dan Zobel, 1997; Ebdon dan Gauch, 2002, Ma et al., 2004; Samonte et al., 2005). Saat ini, grafik biplot juga digunakan untuk interpretasi GGE (Genotipe dan Genotipe dengan Environment) analisis. Melalui grafik GGE biplot dapat menampilkan secara visual evaluasi terhadap genotipe, lingkungan dan interaksinya (Yan et al., 2001; Yan dan Hunt, 2002).
Dua tipe biplot, yaitu AMMI biplot (Zobel et al., 1988) dan GGE biplot (Yan et al., 2001) dapat digunakan untuk visualisasi data interaksi dua faktor. AMMI mengacu pada model statistik pengaruh utama penambahan dan interaksi penggandaan (Gauch dan Zobel, 1997), sedangkan GGE mengacu pada model statistik pengaruh utama genotipe dan interaksi $\mathrm{G}$ dengan E (Yan et al., 2000). Kedua tipe visualisasi grafik biplot menggambarkan interaksi perlakuan dengan lingkungan, tetapi masingmasing memiliki ciri khas yang berbeda.

Penelitian ini bertujuan mendeterminasi pengaruh genotipe, lingkungan dan interaksinya pada sifat kandungan $\mathrm{Fe}$ beras menggunakan analisis grafik GGE Biplot dan menentukan genotipe dan lingkungan terbaik.

\section{Metode Penelitian}

\section{Percobaan Lapangan}

Penelitian dilaksanakan pada musim hujan (mh), Nopember 2007-April 2008 dan musim kemarau (mk), Mei 2008 sampai September 2008. Faktor yang dicoba ada dua, yaitu genotipe padi, dan lingkungan. Genotipe padi yang dicoba ada 10 genotipe, yaitu: yaitu Bahbutong, Cimelati, Fatmawati, Barumun, Aeksibundong, IR 64, Sintanur, Bengawan Solo, Maligaya Special dan Gilirang. Lingkungan yang digunakan ada delapan, yaitu Banyumas mh (E1), Banyumas mk (E5), Baturaden mh(E2), Baturaden mk (E6) Gombong mh (E3), Gombong mk (E7), Cilongok mh(E4) dan Cilongok $\mathrm{mk}$ (E8). Kondisi lingkungan penelitian beragam, yang dicirikan dengan perbedaan kandungan $\mathrm{Fe}$ dalam tanah, tinggi tempat, irigasi dan drainase, lama penyinaran matahari. Rancangan Lapang yang digunakan pada tiap lingkungan adalah Rancangan Acak Kelompok Lengkap, tiga kali ulangan.

\section{Grafik Biplot}

Suatu data dua arah hasil pengamatan (Y), seperti data produksi sejumlah genotipe $(\mathrm{G})$ yang ditanam pada berbagai lingkungan (E), akan mudah dipahami jika disajikan dalam bentuk grafik biplot. Penggambaran data dua arah genotipe - lokasi (Y) dalam grafik biplot, diperlukan proses perhitungan untuk 
mendapatkan dua komponen matrik $\mathrm{G}$ dan $\mathrm{E}$. Proses penguraian suatu tabel dua arah (matrik) menjadi dua komponen matrik perkalian disebut Singular Value Decomposition (SVD).

Pembuatan grafik biplot diperlukan suatu matrik $\mathrm{A}_{v x s}$ yang menggambarkan efek dua factor. Matrik tersebut sebagai subjek SVD. Hasil SVD matrik $\mathrm{A}_{v x s}$ adalah:

$$
\mathrm{A}_{v x s}=\mathrm{U}_{v x r} \Delta_{\mathrm{r} x r} \mathrm{~V}_{\mathrm{r} x s}^{\prime}
$$

$\mathrm{U}_{v x r}$ : adalah matrik yang kolom-kolomnya merupakan eigenvector $\mathrm{A}^{\prime} \mathrm{A}$

$\mathrm{V}_{\mathrm{sxr}}$ : adalah matrik yang kolom-kolomnya merupakan eigenvector $\mathrm{AA}^{\prime}$

$\Delta_{\mathrm{r} x r}$ : adalah matrik diagonal dengan nilai yang tidak nol semakin mengecil

Hasil SVD matrik $\mathrm{A}_{v x s}$ adalah sejumlah $k$ principal component $(\mathrm{PC})$, di mana $\mathrm{k} \leq(\mathrm{v}, \mathrm{s})$. Tiap PC tersusun atas tiga komponen, yaitu singular value $(\lambda)$, eigenvector genotipe $(\alpha)$ dan eigenvector lingkungan $(\gamma)$. Hasil SVD juga dapat ditulis dalam formula :

$$
\mathrm{a}_{\mathrm{ij}}=\sum \lambda_{\mathrm{k}} \alpha_{\mathrm{ik}} \gamma_{\mathrm{jk}}
$$

Model analisis GGE menggunakan formula berikut :

$$
\bar{y}_{i j .}=\mu+e_{j}+\sum_{k=1}^{t} \lambda_{k} \alpha_{i k} \gamma_{j k}+\bar{\varepsilon}_{i j} .
$$

Nilai $\bar{y}_{i j}$. rata-rata genotipe $\mathrm{ke} \mathrm{i}^{\text {th }}$ pada lingkungan $\mathrm{ke} \mathrm{j}^{\text {th }} ; \mu$ adalah rata-rata umum; $g_{i}$ adalah efek genotipe; $e_{j}$ efek lingkungan; $\lambda_{\mathrm{k}}\left(\lambda_{1} \geq \lambda_{2} \geq \ldots \geq \lambda_{\mathrm{t}}\right)$ adalah nilai singular sebagai orthonormal nilai singular vector genotipe, $\quad \alpha_{\mathrm{ik}}=\left(\alpha_{1 \mathrm{k}}, \ldots, \alpha_{\mathrm{gk}}\right)$ dan lingkungan, $\gamma_{\mathrm{jk}}=\left(\gamma_{1 \mathrm{k}}, \ldots, \gamma_{\mathrm{ek}}\right)$, di mana $\sum_{\mathrm{i}} \alpha_{\mathrm{ik}}^{2}=\Sigma_{\mathrm{j}} \gamma_{\mathrm{jk}}^{2}=1$ dan $\sum_{\mathrm{i}} \alpha_{\mathrm{ik}} \alpha_{\mathrm{ik}}=\sum_{\mathrm{j}} \gamma_{\mathrm{jk}} \gamma_{\mathrm{jk}}=0$ untuk $\mathrm{k} \neq \mathrm{k}^{\prime} ; \alpha_{\mathrm{ik}}$ dan $\gamma_{\mathrm{jk}}$ untuk $\mathrm{k}=1,2,3, \ldots$ disebut "primer," "sekunder," "tersier,". . dan seterusnya sebagai efek genotipe dan lingkungan; $\bar{\varepsilon}_{\mathrm{ij}}$. residu error dengan asumsi NID $\left(0, \sigma^{2} / r\right)\left(\right.$ di mana $\sigma^{2}$ pooled error variance dan $r$ jumlah ulangan). Pendugaan kuadrat terkecil dari parameter multiplicative (bilinear) dalam $\mathrm{k}^{\text {th }}$ bilinear didapat sebagai $\mathrm{k}^{\text {th }}$ komponen deviation dari bagian additive (linear) model. Pada model GGE (SREG) efek utama genotipe (G) ditambah GEI masuk dalam batasan bilinear. Penyajian dalam grafik biplot menggunakan dua PC terbesar pertama dan kedua (PC1 dan PC2), sehingga hasil SVD sebagai berikut:

$$
a_{i j}=\lambda_{1} \alpha_{i 1} \gamma_{j 1}+\lambda_{2} \alpha_{i 2} \gamma_{j 2}
$$

dimana $\lambda_{1}$ dan $\lambda_{2}$ merupakan nilai singular PC pertama dan kedua terbesar, yaitu PC1 dan PC2. Kuadrat dari nilai singular PC adalah sama dengan jumlah kuadrat yang dapat diterangkan dengan PC. Nilai $\alpha_{i 1}$ dan $\alpha_{i 2}$ adalah eigenvector genotipe ke $i$ untuk PC1 dan PC2; $\gamma_{j 1}$ dan $\gamma_{\mathrm{j} 2}$ adalah eigenvector lingkungan ke $j$ untuk PC1 dan PC2.

Eigenvector PC1 dan PC2 tidak dapat langsung digunakan untuk pembuatan grafik biplot sebelum nilai singular $(\lambda)$ dibagi kedalam eigenvector genotipe dan lingkungan. Pembagian nilai singular $(\lambda)$ kedalam eigenvector genotipe dan lingkungan menggunakan formula:

$$
\mathrm{g}_{\mathrm{il}}=\lambda_{1}{ }^{\mathrm{fl}} \alpha_{\mathrm{il}} \text { dan } \mathrm{e}_{\mathrm{lj}}=\lambda_{1}{ }^{1-\mathrm{fl}} \gamma_{\mathrm{lj}}
$$

di mana $l$ dapat 1 atau 2 mengacu pada jumlah $\mathrm{PC}$, dan $f l$ adalah faktor pembagi, yang secara teori nilainya antara $0-1$.

\section{Hasil dan Pembahasan}

Hasil anova gabungan dari delapan lingkungan (Tabel 2) menunjukkan bahwa dari total keragaman $(\mathrm{G}+\mathrm{E}+\mathrm{GE})$, pengaruh lingkungan (E) sebesar 74,43\%, pengaruhi genotipe $(\mathrm{G})$ sebesar $5,60 \%$ dan interaksi genotipe dengan lingkungan (GE) sebesar 19,67\%). Pemecahan nilai Jumlah Kuadrat (JK) $\mathrm{G}+\mathrm{GE}$ melalui analisis GGE-biplot menunjukkan bahwa PC1 dan PC2 merupakan faktor nyata yang dapat menjelaskan masingmasing 70,40\% dan $15,36 \%$ dari total $\mathrm{JK} \mathrm{G}+$ GE (Tabel 3).

Pada umumnya data hasil penelitian multi lokasi berupa data campuran interaksi GE tipe interaksi kualitatif (crossover) dan interaksi kuantitatif (noncrossover). Pada penelitian ini terdapat perbedaan genotipe yang menghasilkan Fe beras tertinggi pada lingkungan yang berbeda 
(Tabel 1). Di Banyumas mh (E1) genotipe Gilirang mengasilkan $\mathrm{Fe}$ beras tertinggi, di Baturaden mh (E2) genotipe Maligaya Sp, di Gombong mh (E3) genotipe Bahbutong dan di Cilongok mh (E4) genotipe Barumun yang menghasilkan $\mathrm{Fe}$ beras tertinggi. Perbedaan rangking genotipe antar lingkungan menunjukan ada interaksi GE tipe kualitatif (crossover).

Grafik biplot menampilkan hubungan genotipe dan lingkungan. Grafik GGE biplot digunakan untuk interpretasi hasil analisis $\mathrm{G}+$ GE. Melalui grafik GGE biplot dapat menampilkan secara visual evaluasi terhadap genotipe dan lingkungan (Yan et al., 2001; Yan dan Hunt, 2002).

\section{Interpretasi Score PC Genotipe dan Lingkungan}

Grafik GGE biplot basis skala focusgenotipe menggambarkan lokasi-lokasi suatu genotipe. Genotipe yang memiliki skor PC1 >0 dapat diidentifikasi sebagai genotipe yang memiliki kandungan $\mathrm{Fe}$ beras yang tinggi, sedangkan yang memiliki score PC $1<0$ dapat diidentifikasi sebagai genotipe yang memiliki kandungan $\mathrm{Fe}$ beras rendah, dibanding genotipe lain yang diuji (Gambar 1, Tabel 1). Genotipe Barumun(G4) memiliki kandungan $\mathrm{Fe}$ beras rata-rata yang tertinggi, sedangkan Fatmawati (G3) merupaka genotipe dengan kandungan Fe beras rata-rata terendah.

Score PC2 menggambarkan stabilitas suatu genotipe. Semakin besar score mutlak PC2, semakin tidak stabil keragaan suatu genotipe pada berbagai lingkungan. Berdasarkan scor PC2 (Gambar 1), terdapat beberapa kelompok genotipe. Kelompok genotipe stabil dan Fe beras rendah adalah Gilirang (G10) dan Aeksibundong (G5), kelompok genotipe stabil dan Fe beras tinggi adalah Bengawan solo (G8) Cimelati (G2) dan Barumun (G4), kelompok genotipe tidak stabil dan Fe beras tinggi adalah G6 (IR 64).

Grafik GGE biplot basis skala focuslingkungan menggambarkan estimasi pola suatu lingkungan (Gambar 2). Jika semua genotipe memiliki score $\mathrm{PC} 1>0$ atau $\mathrm{PC}<0$ menggambarkan keragaan yang sejalan genotipe-genotipe pada berbagai lingkungan, yang menunjukkan type non-crossover interaksi GE. Genotipe dengan scor PC1 yang lebih besar dapat dengan mudah diidentifikasi pada lingkungan yang memiliki scor PC1 besar (Yan et al., 2000). Hal yang sama pada scor PC2. Lingkungan yang memiliki scor PC2 kecil (lebih representatif untuk semua lingkungan) dan lingkungan yang memiliki scor PC1 besar (lebih mampu membedakan genotipe dalam batasan efek utama genotipe).

Pada penelitian ini, scor PC1 lingkungan tersebar pada PC1>0 (E2, E3, E4, E6, E7 dan E8) dan pada scor $\mathrm{PC} 1<0$ (E1 dan E5). Demikian juga scor PC2 lingkungan, tersebar pada $\mathrm{PC} 2>0$ (E1, E2, E5, E6, E7 dan E8) dan scor $\mathrm{PC} 2<0$ (E3 dan E4). Kondisi tersebut menunjukkan terjadi interaksi GE yang bersifat kualitatif, yaitu peringkat kandungan $\mathrm{Fe}$ beras genotipe berbeda-beda antarlingkungan (Yan et al., 2000). Suatu genotipe memiliki interaksi positif yang besar dengan suatu lingkungan, namun dengan suatu lingkungan yang lain memiliki interaksi negatif yang besar. Genotipe G4 (Barumun) memiliki kandungan $\mathrm{Fe}$ beras tertinggi pada lingkungan E4 (interaksi positif besar), tetapi memiliki kandungan $\mathrm{Fe}$ beras yang rendah pada lingkungan E1 (interaksi negatif besar), seperti tergambar pada Gambar 3.

Nilai efek interaksi GE yang lebih besar $(19,67 \%)$ dibanding nilai efek utama genotipe $(5,60 \%)$ menunjukkan adanya interaksi GE yang kuat. Hal tersebut ditunjukkan pada scor PC1 dan PC2 lingkungan yang yang tersebar pada semua kuadran (Gambar 2).

\section{Identifikasi Genotipe Terbaik pada tiap Lingkungan}

Visualisasi grafik "which-won-where" dari data hasil penelitian uji multilokasi penting untuk mempelajari keberadaan kondisi lingkungan yang berbeda beda pada suatu wilayah (Gauch and Zobel, 1997; Yan et al., 2000, 2001). Pola poligon pada grafik biplot merupakan cara yang terbaik untuk visualisasi pola interaksi antara genotipe dengan lingkungan dan sangat efektif untuk interpretasi biplot (Yan dan Kang, 2003).

Titik sudut pola poligon grafik biplot pada penelitian ini (Gambar 4) adalah G4 (Barumun), G 9 (Maligaya Sp.), G3 (Fatmawati) dan G6 (IR 64). Genotipe yang menjadi titik sudut poligon untuk tiap sektor adalah genotipe yang menghasilkan Fe beras tertinggi pada lingkungan 
yang berada pada sektor yang sama. Hanya ada dua sektor di antara empat sektor yang ditempati titik lingkungan. Genotipe G4 (Barumun) menghasilkan $\mathrm{Fe}$ beras tertinggi pada E4 (Cilongok mh), G9 (Maligaya Sp.) menghasilkan Fe beras tertinggi pada E1 (Banyumas mh) dan E2 (Baturaden mh). Genotipe G3 (Fatmawati) dan G10 (Gilirang) menghasilkan $\mathrm{Fe}$ beras terendah pada semua lingkungan (Gambar 4). Keberadaan genotipe dan lingkungan yang berada pada dua sektor yang berlawanan arah dengan jarak terjauh menunjukan bahwa genotipe tersebut berinteraksi negatif paling besar dengan lingkungan tersebut. Genotipe G3 (Fatmawati) menghasilkan $\mathrm{Fe}$ beras terendah dibanding genotipe lain pada lingkungan E4 (Cilongok mh), genotipe G6 (IR 64) menghasilkan $\mathrm{Fe}$ beras terendah pada lingkungan E2 (Baturaden mh).

\section{Keragaan Rerata dan Stabilitas Genotipe}

Keragaan hasil dan stabilitas suatu genotipe dapat dievaluasi dengan metode koordinat rerata lingkungan atau AEC (Yan, 2001; Yan and Hunt, 2002; Yan 2002). Pada metode ini, rata-rata lingkungan didefinisikan dengan rerata skor PC1 dan PC2 semua lingkungan, digambarkan dengan lingkaran kecil pada grafik GGE biplot (Gambar 5). Garis lurus yang melewati titik koordinat rerata lingkungan (AEC) dengan titik asal biplot disebut aksis rerata lingkungan, yang berperan sebagai absis AEC (satu ujung tanda panah). Sebagai ordinat AEC adalah garis lurus yang melalui titik asal biplot dan tegak lurus AEC (dua ujung tanda panah). Absis AEC mengikuti arah tanda panah menunjukkan semakin besar efek utama genotipe. Ordinat AEC membagi genotipegenotipe yang memiliki rerata $\mathrm{Fe}$ beras lebih tinggi dari rerata umum dengan genotipegenotipe yang memiliki rerata $\mathrm{Fe}$ beras lebih rendah dari rerata umum. Genotipe yang miliki rerata $\mathrm{Fe}$ beras lebih tinggi dari rerata umum adalah G4 (Barumun), G6 (IR64) dan G9 (Maligaya Sp.), sedangkan genotipe yang lain dibawah rerata umum. Arah pada ordinat AEC yang menjauh dari titik asal biplot menunjukkan efek interaksi GE yang semakin besar dan menurunnya stabilitas.

\section{Identifikasi Genotipe Ideal}

Suatu alat yang dapat digunakan pada analisis GGE biplot untuk identifikasi genotipe superior dan lingkungan ideal yang dapat untuk identifikasi suatu genotipe adalah korelasi yang tinggi antara scor PC1 genotipe dan rerata hasil genotipe (Yan et al., 2000; Yen et al., 2001; Yan and Rajcan, 2002; Crossa et al., 2002). Menurut Yan and Rajcan (2002), genotipe ideal adalah genotipe yang memiliki scor PC1 besar (rerata hasil tinggi) dan scor absolut PC2 kecil (stabilitas tinggi).

Panjang vektor AEC merupakan ukuran relatif pentingnya efek utama genotipe dibanding interaksi GE. Semakin panjang, yang lebih penting adalah efek utama genotipe, yang berarti seleksi berdasar pada rerata keragaan. Genotipe yang memenuhi kriteria tersebut adalah G4 (Barumun), sehingga dapat dipilih (Gambar 5). Dipihak lain, stabilitas genotipe juga penting. Dengan demikian, G4 (Barumun) di samping Fe beras paling tinggi juga paling stabil dibanding genotipe lain, sehingga merupakan genotipe ideal.

\section{Identifikasi Lingkungan Ideal}

Lingkungan ideal yaitu lingkungan yang memiliki scor PC2 kecil (lebih representatif untuk semua lingkungan) dan memiliki scor PC1 besar(lebih mampu membedakan genotipe dalam batasan efek utama genotipe). Pada Gambar 2, urutan rangking lingkungan berdasarkan tingkat paling representatif (scor PC2) adalah E3 (Gombong mh), E8 (Cilongkok mk), E6 (Baturaden mk), E5 (Banyumas mk), E4 (Cilongok mh), dan E2 (Baturaden mh). Urutan rangking lingkungan berdasarkan batasan kemampuannya untuk membedakan genotipe (scor PC1) adalah E4 (Cilongok mh), E2 (Baturaden mh), E7 (Gombong mk), E3 (Gombong $\mathrm{mh}$ ) dan E6 (Banyumas $\mathrm{mh}$ ). Berdasarkan hasil tersebut, lingkungan yang ideal untuk seleksi genotipe-genotipe pada sifat kandungan Fe beras adalah E4 (Cilongok mh).

\section{Korelasi Antarlingkungan}

Korelasi antarlingkungan juga dapat tersaji dalam grafik GGE biplot. Vektor yang tergambar pada grafik GGE biplot menggambarkan hubungan (korelasi) antarlingkungan (Yan, 2002). Vektor antar 
lingkungan membentuk sudut dengan besaran tertentu. Nilai cosinus sudut yang dibentuk antardua lingkungan mengambarkan nilai koefisien korelasi antar kedua lingkungan tersebut (Gambar 2). Semakin kecil sudut yang terbentuk antara vektor dua lingkungan $\left(<90^{\circ}\right)$, semakin erat hubungan antara kedua lingkungan tersebut, jika membentuk sudut $90^{\circ}$ berarti tidak ada korelasi (koefisien korelasi $\mathrm{r}=0$ ), jika membentuk sudut $>90^{\circ}$ berarti berkorelasi negatif $(\mathrm{r}<0)$. Lingkungan E4 (Cilongok mh) berkorelasi positif dengan E3 (Gombong mh), berarti keragaan suatu genotipe yang diuji pada lokasi E4 (Cilongok mh) sejalan dengan di lokasi E3 (Gombong mh). Sebaliknya, lingkungan E4 (Cilongok $\mathrm{mh}$ ) berkorelasi negatif dengan E1 (Banyumas $\mathrm{mh}$ ), berarti keragaan suatu genotipe yang diuji pada lokasi E4 (Cilongok mh) bertolak belakang dengan keragaannya jika ditanam di E1 (Banyumas mh). Ukuran panjang vektor lingkungan juga menggambarkan besaran standar deviasi pada lingkungan tersebut. Semakin panjang garis vektor, semakin besar standar deviasi keragaan genotipe-genotipe pada lingkungan tersebut, yang berarti semakin besar kemampuan membeda-bedakan antargenotipe.

Tabel 1. Kandungan Fe beras (ppm) 10 genotipe pada 8 lingkungan.

\begin{tabular}{|c|c|c|c|c|c|c|c|c|c|}
\hline \multirow[b]{2}{*}{ Genotipe } & \multicolumn{2}{|c|}{ Banyumas } & \multicolumn{2}{|c|}{ Baturaden } & \multicolumn{2}{|c|}{ Gombong } & \multicolumn{2}{|c|}{ Cilongok } & \multirow[b]{2}{*}{ Rerata Genotipe } \\
\hline & (E1) & (E5) & (E2) & (E6) & (E3) & (E7) & (E4) & (E8) & \\
\hline "G1 (Bahbutong) & 20,60 & 6,76 & 1414,72 & 9,68 & 24,80 & 10,51 & 46.26 & 20,51 & 19,22 \\
\hline G2 (Cimelati) & 18,04 & 9,27 & 16,93 & 13,52 & 16,55 & 16,40 & 48.20 & 23,44 & 20,29 \\
\hline G3 (Fatmawati) & 15,08 & 8,72 & 13,52 & 13,29 & 14,39 & 9,31 & 25.08 & 23,08 & 15,31 \\
\hline G4 (Barumun) & 18,63 & 8,25 & 30,70 & 16,67 & 19,96 & 16,46 & 77.70 & 28,87 & 27,15 \\
\hline G5 (Aeksibundong) & 20,58 & 9,70 & 20,85 & 9,70 & 12,34 & 10,92 & 45.50 & 20,14 & 18,71 \\
\hline G6 (IR 64) & 21,58 & 7,73 & 13,21 & 14,27 & 9,42 & 16,14 & 64.05 & 24,86 & 21,41 \\
\hline G7 (Sintanur) & 22,04 & 8,89 & 13,49 & 12,35 & 20,17 & 8,37 & 45.49 & 21,48 & 19,03 \\
\hline G8 (Bengawan solo) & 22,55 & 10,52 & 16,74 & 11,77 & 13,29 & 10,77 & 53.34 & 23,75 & 20,34 \\
\hline G9 (Maligaya Sp) & 29,05 & 11,85 & 32,49 & 14,18 & 15,93 & 18,97 & 35.03 & 23,18 & 22,58 \\
\hline G10 (Gilirang) & 29,98 & 8,07 & 14,25 & 13,35 & 9,30 & 10,45 & 29.00 & 23,55 & 17,25 \\
\hline Rerata Lokasi & 21,81 & 8,98 & 18,69 & 12,88 & 15,62 & 12,83 & 46.96 & 23,29 & \\
\hline
\end{tabular}

Tabel 2. Hasil Anova gabungan genotipe, lingkungan dan interaksi genotipe dengan lingkungan.

\begin{tabular}{|c|c|c|c|c|c|c|c|}
\hline$\overline{\text { Sumber Keragaman }}$ & DB & JK & KT & $\mathbf{F}$ & $\mathbf{P}>\mathbf{F}$ & Model & JK (\%)* \\
\hline Lingkungan & 3 & 29569,269 & 44224,181 & $\overline{5577,70}$ & $2<.0001$ & Random & 74,42 \\
\hline Ul (Lingk) & 16 & 12,098 & 0,756 & 1,00 & 0.5502 & & \\
\hline Genotipe & 9 & 2222,953 & 246,994 & 326,14 & $<.0001$ & Fixed & 5,60 \\
\hline Genotipe dengan & 63 & 7817,099 & 124,081 & 163,84 & $<.0001$ & Random & 19,67 \\
\hline $\begin{array}{l}\text { Lingkungan } \\
\text { Error }\end{array}$ & 144 & 109,056 & 0.757 & & & & \\
\hline Total & 239 & 39730,477 & & & & & \\
\hline
\end{tabular}

Keterangan: *) persentase terhadap total JK G, E dan GE

Tabel 3. Analisis GGE biplot kandungan Fe beras 10 genotipe pada 8 lingkungan.

\begin{tabular}{lcrrr}
\hline \hline Principal Component & Singular Values & Eigen Values & Total Eigen Values (\%) & \multicolumn{1}{c}{ Kumulative (\%) } \\
\hline PC1 & 84,07 & 7068,15 & 70,40 & 70,40 \\
PC2 & 39,28 & 1542,76 & 15,36 & 85,76 \\
PC3 & 27,69 & 767,13 & 7,64 & 93,40 \\
Residu & & 662,00 & 6,60 & 100,00 \\
Total & & $10040,04 *)$ & & \\
\hline
\end{tabular}

*) Total eigen values sama dengan total Jumlah Kuadrat (JK) Genotipe + (Genotipe dengan Lingkungan) 
CGE Biplat Kandungon Fe Beras

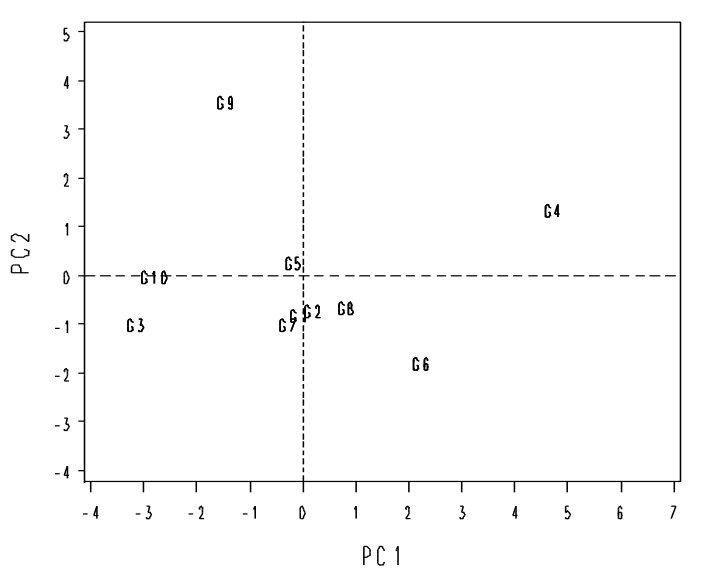

Gambar 1. Grafik GGE Biplot fokus genotipe basis skala simetris.

GGE Biplol Kondungon Fe Beros

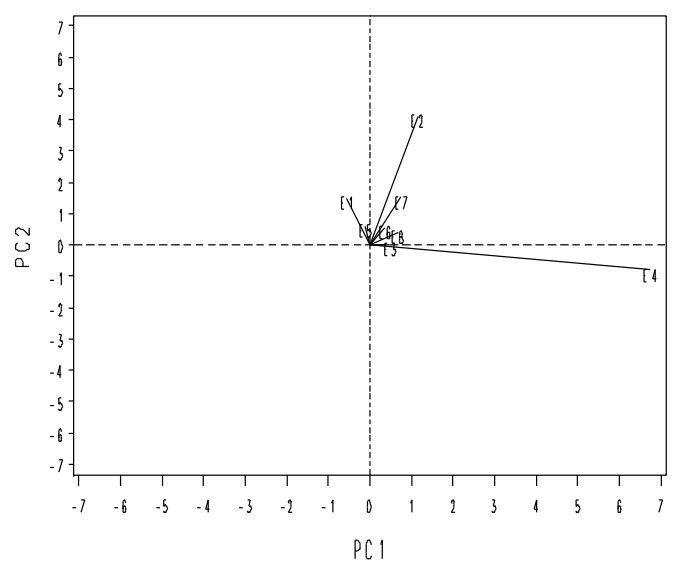

Gambar 2. Grafik GGE Biplot fokus lingkungan basis skala simetris.

GGE Biplat Kondungan Fe Beros

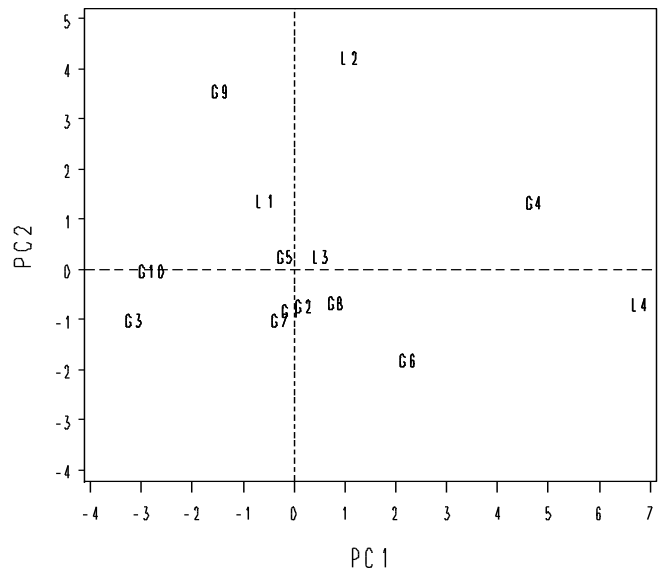

Gambar 3. Grafik GGE Biplot genotipe dan lingkungan basis skala simetris. 
GCE Biplot Kandungon Fe Beras

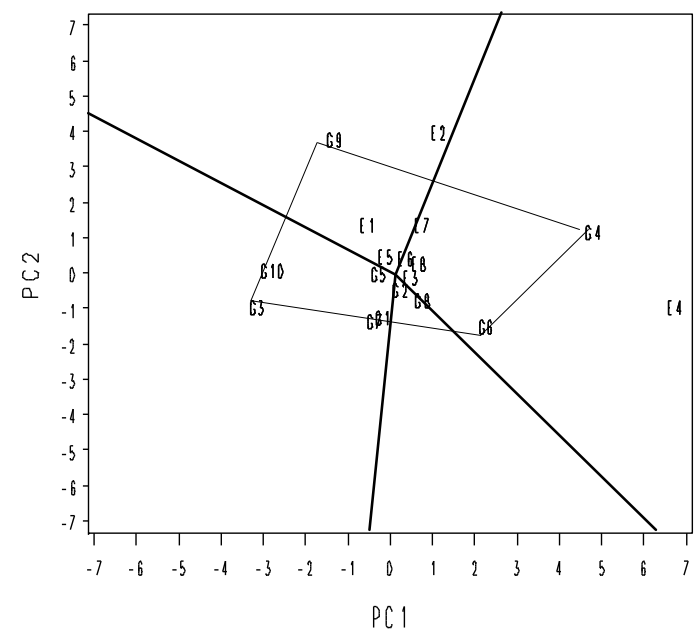

Gambar 4. Grafik GGE Biplot basis skala simetris untuk pola "which-won-where".

GGE Biplot Kandungan Fe Beros

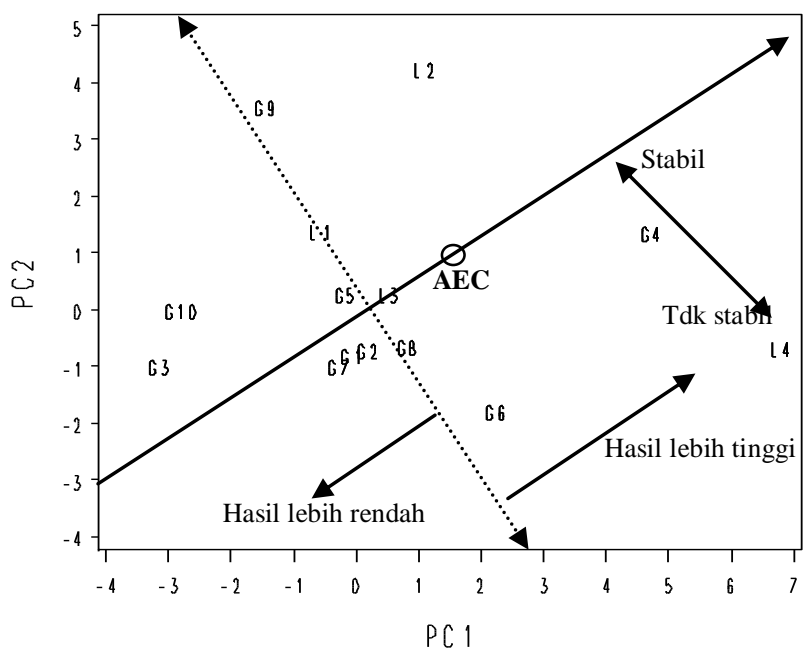

Gambar 5. Koordinat rerata lingkungan pada grafik GGE Biplot basis skala simetris.

\section{Simpulan dan Saran}

\section{Simpulan}

Berdasarkan penelitian di atas dapat disimpulkan bahwa lingkungan, genotipe dan interaksinya berpengaruh nyata terhadap kandungan Fe beras. Genotepe G4 (Barumun) merupakan genotipe ideal, memiliki konsentrasi $\mathrm{Fe}$ beras tertinggi dan paling stabil. Lingkungan E4 (Cilongok mh) merupakan lingkungan terbaik, paling representatif mewakili semua lingkungan dan paling kuat untuk membedakan genotipe.

\section{Saran}

Padi genotipe Barumun dapat dikembangkan untuk meningkatkan kuantitas (produksi) dan kualitas (kandungan $\mathrm{Fe}$ ) beras, dalam rangka meningkatkan ketersediaan pangan dan meningkatkan asupan Fe bagi masyarakat.

\section{Ucapan Terima Kasih}

Atas terlaksananya penelitian dan tersusunnya artikel ini penulis mengucapkan terima kasih kepada Dekan Fakultas Pertanian UGM atas pemberian izin dan fasilitas laboratorium untuk pelaksanaan penelitian. 


\section{Daftar Pustaka}

Bridge, W.C.,Jr. 1989. Analysis of Plant Breeding Experiment with Heterogeneous Variance using Mixed Model Equation. Pp. 145-151. In. Applications of mixed models in agriculture and related discipline. So. Coop. Ser. Bull. No. 343. Lousiana Agricultural Experiment Station, Baton Rouge, LA.

Busey, P. 1983. Crop Breeding. In: Wood, D.R., Rawal, K.M. dan Wood, M.N. (Eds.). Management of crop breeding. Pp. 31-54. American Society of Agronomy, Crop Science Society of America, Madison.

Crossa, J., Cornelius, P.L. dan Yan, W. 2002. Biplots of Linear-bilinear Models for Studying Crossover Genotipe x Environment Interaction. Crop Sci., 42: 619-633.

Ebdon, J.S. dan Gauch, H.G. 2002. Additive Main Effect and Multiplicative Interaction Analysis of National Turgrass Performance Trials: Interpretation of Genotype $\mathrm{x}$ Environment Interaction. Crop. Sci., 42: 489-496.

Gauch, H.G.Jr. dan Zobel, R.W. 1997. Identifying Mega Environments and Targeting Genotypes. Crop. Sci., 37: 311-326.

Graham, R.D. dan Welch, R.M. 2002. Breeding for StapleFood Crops with High Micronutrient Density: Agricultural Strategies for Micronutrients Working Paper 3 1996: 1-72 International Food Policy Research Institute Washington, DC.

Graham, R.D. dan Welch, R.M. 2004. Breeding for StapleFood Crops with High Micronutrient Density. Agricultural Strategies for Micronutrients Working Paper No. 3. Washington, DC: International Food Policy Research Institute, 172 .

Gregorio, G.B., Hass, J.D., Beard, J.L. Murray, L.E., del Mundo, A.M. dan Felix, A. 2005. IronBiofortified Rice Improves the Iron Store of Nonanemic Fillipino Women. J. Nutr., 135: 2823-2830.

Ma, B.L., Yan, W., Dwyer, L.M., Fregeau-Reid, J., Voldeng, H.D., Dion, Y. dan Nass, H. 2004. Graphic Analysis of Genotype, Environment, Nitrogen Fertilizer, and their Interactions on Spring Wheat Yield. Agron. J., 96: 169-180.
Samonte, S.O.P.B., Wilson, L.T., McClung, A.M. dan Medley, J.C. 2005. Targeting Cultivar Onto Rice Growing Environment using AMMI and SREG GGE Biplot Analysis. Crop Sci., 45: 2414-2424.

Shafii, B. dan Price, W.J. 1998. Analysis of Genotype-byEnvironment Interaction using Additive Main Effects and Multiplicative Interaction model and Stability Estimates. J.Agric. Biol. Environ. Stat., 3: 335-345.

Winarsi, H. 2007. soflavon Kedelai Diperkaya dengan Zn sebagai Suplemen Antiarterosklerosis Wanita Premenopause. Biota, 12 (2): 70-77.

Yan, W., Hunt, L.A., Sheng, Q. dan Szlavnics, Z. 2000. Cultivar Evaluation and Mega-environment Investigation Based on GGE biplot. Crop. Sci., 40: 507-605.

Yan, W., Cornelius, P.L., Crossa, J. dan Hunt, L.A. 2001. Two Types of GGE Biplot for Analyzing MultiEnvironment Trial Data. Crop. Sci., 41: 656-663.

Yan, W. 2001. GGE Biplot - a Windows Application for Graphical Analysis of Multienvironment Trial Data and Other Types of Two-way Data. Agron. J., 93: 1111-1118.

Yan, W. 2002. Singular Value Partitioning in Biplot Analysis of Multienvironment Trial Data. Agron. J., 94: 990-996.

Yan, W. dan Hunt, L.A. 2002. Biplot Analysis of Diallel Data. Crop Sci., 42: 21-30.

Yan, W. dan Racjan, I. 2002. Biplot Analysis of Test Site and Trait Relations of Soybean in Ontario. Crop Sci., 42: 11-20.

Yan, W. dan Kang, M.S. 2003. GGE Biplot Analysis: A Graphical Tool for Breeders, Geneticist, and Agronomists. CRS PRESS. Boca Raton, FL.

Zobel, R.W., Wright, M.J. dan Gauch, Jr.H.G. 1988. Statistical Analysis of a Yield Trial. Agron. J., 80: 388-393. 